extensive and intensive that he made no pretence of keeping pace with it.

(2) Prof. Leche's book made its first appearance in Swedish at the time of the Darwin celebrations in rgog, and when the time came for the preparation of a second edition he made his interesting work available to a wider circle of readers by issuing this German edition.

The book is a simple and lucid description of the growth of evolutionary ideas, with an account of the men to whom we are indebted for this new learning.

Unlike Haeckel's treatise, which takes the form of lectures addressed to students of biology, but in virtue of its lucidity has become, nevertheless, a popular treatise, Leche's book is obviously written for the educated public in general, and therefore omits certain topics discussed by Hacckel, which are properly included in a treatise on biology, but not in works for wider circulation.

It is somewhat disappointing to the biologist familiar with the author's important contributions to comparative anatomy that Prof. Leche should have chosen to cast his book in so popular a mould. It would have been instructive to have had more information concerning the higher primates from one who is so great an authority on the other end of the mammalian phylum. But Prof. Leche has chosen the rôle of expositor, mainly of other people's work, and we are duly grateful for his clear statement of generally accepted views regarding man's origin and developmental history.

The book opens with an exposition of the growth of the theory of evolution, with an account of the work of Charles Darwin, his predecessors, co-worlers, and followers, and it discusses the modern conflict between the teaching of Weismann and "NeoLamarkismus," expressing the opinion, for which he claims the support of Darwin himself, that the origin of species can be explained only by admitting the potency of the essential factors emphasised by both schools.

The second chapter is a simple exposition of man's place in the vertebrate series, explained by reference to the facts of comparative anatomy and embryology. Chapter iii. gives an account of the nature of the palæontological record, and deals at some length with the histories of the various vertebrate groups that have been recovered bv this means, most of the space devoted to mammals being filled by the familiar story of the horse. The next three chapters deal respectively with man's structure as illuminated by comparison with that of other vertebrates; the light thrown on man's development by comparative embryology; and the nature and significance of rudimentary organs in the human body, the pineal body, the third eyelid, the palatal ridges, the coccyx, superfluous hair and teeth, and the vermiform appendix being the vestigial structures selected for discussion. There is a brief chapter on the brain, which can scarcely be considered adequate when it is remembered that it is the organ which has played the chief part in making man what he is.

The closing chapters are perhaps most useful to the zoological reader. They deal with man's nearest No. 2 I 76 , VOL. 87$]$ relatives, the primates, fossil-man and Pithecanthropus.

It is gratifying to find that Prof. Leche lends the weight of his support to the view, first set forth in Nature in the year 1907 , that Tarsius is the slightly specialised living representative of a very primitive group of primates, from which the lemurs and the apes were derived by specialisation along divergent lines; that in this sense Tarsius is the connecting link between these two suborders, because it is the least modified descendant of the common parents of all three suborders of primates.

There is a very useful summary of the circumstances of the discovery of the remains of Palæolithic man and Pithecanthropus, with an unbiassed account of the nature and significance of these much-discussed relics of fossil-man. In the chapters dealing with this subject he follows Schwalbe in most matters, and describes the recent trend of opinion on the Continent in reference to Palæolithic man, without committing himself, however, to any of the extreme views that are so much in evidence at the present time.

The volume closes with a brief statement in reference to certain points in the anatomy of modern man that have some wider significance of racial or sociological importance.

Prof. Leche's book can be heartily recommended as a calm and dispassionate summary of the present state of our knowledge of the structure of man, as it is interpreted by comparative anatomy. G. E. S.

GEOLOGY AND BUILDING STONES.

(i) The Geology of Building Stones. By J. Allen Howe. Pp. viii +455 . (London : E. Arnold, Igio.) Price $7 s$. 6d. net.

(2) British and Foreign Building Stones: a Descriptive Catalogue of the Specimens in the Sedgwick Museum, Cambridge. By John Watson. Pp. viii + 484. (Cambridge: University Press, I9Ir.) Price $3 s$. net.

(I) THERE has long been a demand for a book such as that now produced by Mr. Howe. It would be well for all architects, and also engineers, to go through some short course of geological training, leading up to the understanding of a geological map. Mr. Howe has to meet those cases where no preliminary work has been possible, and he describes in a clear manner the essential characters of rockforming minerals. Quaintly, but properly enough, he includes ice, the mineral most utilised by the Eslkimo. Knowing as he does the utility of the microscope, he introduces extinction angles in the table of the felspars on p. 20 , but these are left unexplained, and the variation in the angle between the cleavages would surely be more interesting to the beginner. Thin sections of typical rocks are well illustrated in the later pages. The work of Dr. Flett, Mr. Lovegrove, and the author, has probably introduced the microscope to many "practical" men with good effect.

The classification of rocks employed is commendably simple. Trachyte seems to have slipped out of the table on p. 43, as a parallel with rhyolite and andesite, though it is described on p. Io3. Mr. Howe 
does very well in avoiding local and specialised rocknames, though we suppose "kentallenite" (p. 89), the incorrect but accepted use of "granophyre" (p. 92), and "keratophyre" could scarcely be kept out. A large part of the book is naturally devoted to sedimentary rocks, and no reader will fail to appreciate their structure, and the interesting way in which structure records their modes of origin. The treatment of slate is an excellent example; we note that chemical composition is here so dominated by the compactness and by the fissile structure of the rock as to have no effect on relative durability (p. 287). Limestones are also adequately dealt with, the important oolitic stones of England being described in considerable detail. Among sandstones, we may direct attention to the interesting account of the Surrey "firestone" on p. 166. There is much in this book which will enable the professional geologist to give a "practical" touch to his teaching, and thus in turn to attract the technical student towards the broader aspects of geology. One of the chief rewards of the instructor in a modern college is to note the pleasure aroused when some familiar feature is explained. The "practical man" may know a good deal already about a stone, but he now sees it taking its place in the history of a world of stones.

Mr. Howe's chapter on the decay of building stone is especially to the point. He uses chemical symbols at times in his text in place of words, which is scarcely literary; but he shows well how sodium chloride and other salts increase the attack of rainwater on a stone, and how the acids liberated in towns also play their destructive part. A special section is devoted to the decay of limestones. The deleterious formation of gypsum in parts of buildings sheltered from the rain, or even beneath rain-washed surfaces, is impressively pointed out. Crystalline dolomites (p. 353) decay in the country through the more rapid solution of any calcite granules that are present, while in towns a worse evil befalls them, from the fact that magnesium sulphate is even more soluble than gypsum. The sulphuric acid in towns, of course, arises from the iron pyrites contained in coal. Mr. Howe's remarks as to our love for limestone (p. 9) should be taken to heart by architects.

There is a useful chapter on the testing of stones; but we question if the appendices which follow, containing lists of quarries, were worth compiling in view of the far more complete lists issued by the Home Office, and referred to on p. 435. A liberal description, however, not merely an enumeration, is given of the sandstones of Ireland (the heading accidentally calls them limestones). The reason for this treatment is not apparent, since a reference to the source of information, Kinahan's "Economic Geology of Ireland," would show that a similarly detailed essay might be written on any class of Irish stone.

It is one of the curses of curators that manuscript labels lead to cumulative errors in the names of places. Mr. Howe has succeeded far better than any copyist would have done. We do not know if his variations from Kinahan are accidents or corrections, for Kinahan was indifferent to proof-reading; but such words as Dundale, Geradmer, Blekinje, Thuringewald,
Böhm-Brod, and Maenturog require emendation. Why write "the Tyrol," and also "Steiermarls" and "Mähren"? But at such a book-the metaphor is obvious-we would not willingly cast a stone. We are additionally grateful for an index of twenty pages.

(2) Mr. John Watson's work represents an immense amount of patient application, behind which lies real enthusiasm. He has brought together a collection of building stones for the Sedgwick Museum in Cambridge, in which he aims at representing the whole world. He has presented a large number of the specimens, and furnishes a catalogue of rocks used in construction, leaving those used for decoration, roadmaking, and roofing for future work. On p. 8 he approves "a suggestion" that the University of Cambridge might be a fit place for "a national bureau, where building stone could be examined, tested, and reported on." The existence of the Geological Survey, of Great Britain, as a public body of the first standing, would no doubt occur to our legislators, and the difference of outlook adopted in an economic and in a university museum is at once seen by Mr. Watson's choice of a classification. His stratified building stones are arranged according to their geological age, and are then grouped under their countries of origin. It is a question if this appeals even to the university student of petrology, and it certainly conveys no useful information to the seeker after building stones. The admirable index of fifty pages, surpassing that of the diligent $\mathrm{Mr}$. Howe, does not set matters straight. There are thus twenty-six references to oolites, even though the Caen stone of p. I84 is omitted; but the seeker after sandstone will have to turn the pages of the volume. Granites, however, are copiously indexed as a group. The universities, having adopted law and medicine, have proceeded to engineering, mining, and distilling. It may now be too late to leave building construction and building stones to great technical colleges, of the type of the Royal School of Mines. Mr. Watson's book, issued at so very moderate a price, is a treasury of information for the inquirer. It is not the author's fault if it seems to emphasise that overlapping of functions which threatens to impoverish British centres of education.

G. A. J. C.

\section{SUPERNORMAL PSYCHOLOGY.}

(1) New Evidences in Psychical Research. A Record of Investigations, with Selected Examples of Recent S.P.R. Results. By J. Arthur Hill. With an introduction by Sir Oliver Lodge, F.R.S. Pp. xiit 2I8. (London: Wm. Rider and Son., Ltd., I9II.) Price $3 s, 6 d$. net.

(2) Personality and Telepathy. By F. C. Constable. Pp. $x v+330$. (London: Kegan Paul and Co., Ltd., IorI.) Price $7 s .6 d$. net.

T $T$ was in the early 'seventies of last century that 1 men of scientific training began to take an interest in certain mental and physical phenomena which appeared to transcend the ordinary laws of psychology and biology. It has taken a generation to acclimatise some of these phenomena in the realm of serious and orthodox scientific pursuit, and the two present NO. 2176 , VOL. 87$]$ 